\title{
GIS-Based Sub-Basin Scale Identification of Dominant Runoff Processes for Soil and Water Management in Anambra Area of Nigeria
}

\author{
Babatunde Joseph Fagbohun ${ }^{1 *}$, Oluwaseun Franklin Olabode ${ }^{2}$, Abiodun Olufemi \\ Adebola $^{1}$, Francis Omowonuola Akinluyi ${ }^{1}$ \\ ${ }^{I}$ Department of Remote Sensing and Geoscience Information System, Federal University of Technology, P.M.B \\ 704, Akure, Nigeria. \\ ${ }^{2}$ Department of Applied Geology, Federal University of Technology, P.M.B 704, Akure, Nigeria. \\ *Corresponding author's emails: jfahb328@gmail.com; bjfagbohun@futa.edu.ng \\ Phone: +2347035782585
}

Received: $20^{\text {th }}$ April, 2017

Accepted: $5^{\text {th }}$ November, 2017

\begin{abstract}
Identifying landscapes having comparable hydrological characteristics is valuable for the determination of dominant runoff process (DRP) and prediction of flood. Several approaches used for DRP-mapping vary in relation to data and time requirement. Manual approaches which are based on field investigation and expert knowledge are time demanding and difficult to implement at regional scale. Automatic GIS-based approach on the other hand require simplification of data but is easier to implement and it is applicable on a regional scale.

In this study, GIS-based automated approach was used to identify the DRPs in Anambra area. The result showed that Hortonian overland flow (HOF) has the highest coverage of $1508.3 \mathrm{~km}^{2}(33.5 \%)$ followed by deep percolation (DP) with coverage of $1455.3 \mathrm{~km}^{2}(32.3 \%)$. Subsurface flow (SSF) is the third dominant runoff process covering $920.6 \mathrm{~km}^{2}(20.4 \%)$ while saturated overland flow (SOF) covers the least area of $618.4 \mathrm{~km}^{2}$ $(13.7 \%)$ of the study area. The result reveal that considerable amount of precipitated water would be infiltrated into the subsurface through deep percolation process contributing to groundwater recharge in the study area. However, it is envisaged that HOF and SOF will continue to increase due to the continuous expansion of builtup area. With the expected increase in HOF and SOF, and the change in rainfall pattern associated with perpetual problem of climate change, it is paramount that groundwater conservation practices should be considered to ensure continued sustainable utilization of groundwater in the study area.
\end{abstract}

Key words: dominant runoff process, GIS, remote sensing

\section{Introduction}

Determination of Dominant Runoff Processes (DRPs) is essential towards planning water conservation measures such as identification of groundwater recharge zones, reduction of the flooding and erosion hazards, as well as monitoring of sedimentation in downstream areas. Detailed knowledge of the spatial distribution of the DRPs in a catchment allows thorough understanding of runoff generation and offers a tool to determine the contributing areas under different rainfall characteristics and initial catchment conditions (Bonell 1998). It can also help to improve hydrological simulations particularly for ungauged basins. Different types of runoff processes can take place on one site, however the dominant one is the one which contributes most to the runoff, hence other processes can be neglected (Müller et al. 2009; Scherrer and Naef 2001). The dominant process is predominantly dependent on the site characteristics and the nature of rainfall event. The DRP on a particular site for a given rainfall event is the process that 
contributes the most to runoff (Naef et al. 2002).

DRP can be classified as Hortonian overland flow (HOF), saturated overland flow (SOF), subsurface flow (SSF) and deep percolation (DP) (Scherrer and Naef 2003). Runoff or overland flow is the net liquid water which flows over natural ground surface after interception, surface retention, evaporation, infiltration and percolation to underlying aquifers (Aladejana et al. 2016; Sharma et al. 2001). Overland flow involves the movement of water over the land, downslope toward a surface water body. Runoff is the major cause of flash floods and it is also the main force behind sheet erosion (Fagbohun et al. 2016). The HOF occur when rainfall intensity exceeds the rate of infiltration into the ground and all surface storage has been filled. Water accumulates on the soil and starts moving downslope, due to gravity, towards the hydrographic network. It commonly occur in arid and semi-arid regions where rainfall intensities are high and soil infiltration has been reduced. It is also the dominant process in built-up areas where the ground is paved or soils have become compacted. SOF on the other hand occur when soil is saturated and depression storage are filled due to groundwater uplifting, baseflow, and lateral subsurface water discharges, the continued downpour of rain result in SOF. The antecedent moisture content of soil is a major factor that influences the time it takes soil to become saturated (Gliński et al. 2001). SSF generally results if an impermeable horizon or impermeable substratum occurs on a steep slope having less shallow or very shallow soil with efficient system of lateral flow paths. However DP is expected to dominate where thick permeable soils or shallow permeable soils overlie very permeable subsoil and substratum (Scherrer and Naef 2003).

Many approaches exist for determining the DRP of an area. Nevertheless the approach developed by Scherrer and Naef (2003) which is derived from large number of field- and sprinkling experiments is the foundation for developing process decision schemes to determine DRPs which occur on a soil profile after prolonged rainfall events. The data required for the method comprise of sixteen (16) datasets: topographical maps; soil profiles; soil maps; vegetation maps; geomorphological maps; geological maps; geotechnical maps; hydrological maps; geoecological maps; infiltration tests; drilling points with soil description; digital maps (ATKIS); agricultural land evaluation; forestry maps; remotely sensed data and drainage plans (Müller et al. 2009). Scherrer and Naef (2003) pointed out that the drawbacks of this approach is that infiltration of rains with low intensity into the soil occur predominantly by matrix flow and their method does not account for such conditions.

Several techniques have been proposed to identify and delineate the area extent of regions where a particular runoff process can take place particularly in micro-scale basin (e.g Faeh 1997; Scherrer and Naef 2001) which are suitable for regionalization purposes. Classifications of DRP can be achieved through manual or automatic approach. While manual approaches require extensive field investigations, interpretation and upscaling of the results based on expert knowledge, the automatic methods on the other hand greatly depend on algorithms and GIS-based simplifications by expert (Antonetti et al. 2016). Automatic approaches differ in the type of data requirement. Some rely solely on topographic information (Gharari et al. 2011) while others employ all available information (Schmocker-Fackel et al. 2007). The result of both manual and automated approaches is a DRP-map which represent the spatial distribution of the hydrological behaviour of the soils under prolonged rainfall events (Müller et al., 2009), however the resulting DRP classes vary on the methods. While all methods differentiate between SSF and DP, 
and between HOF and SOF, several approaches further subdivide SOF process as DSOF1, DSOF2 and DSOF3 and SSF process as DSSF1, DSSF2 and DSSF3 based intensity (Antonetti et al. 2016), where numbers 1 to 3 represent the lag time in the reaction to rainfall. Thus, 1 represents nearly instantaneous reaction, and 2 represents somewhat delayed reaction, while 3 represents a prolonged delay (Müller et al. 2009; Scherrer and Naef 2003; Schmocker-Fackel et al. 2007).

Field experiments emphasized the significant role of the nature of infiltration at surface topsoil interface on runoff development. Due to the complexity associated with this interface in forests and on arable land as compared to grassland, special decision schemes is required for these land use/cover types. A statistical or geo-statistical analysis of DRP which does not include the use of detailed soil maps may well offer an insight into their regionalization potential (Müller et al. 2009). Subsequently, a GIS-based simplification of Schmocker-Fackel et al. (2007) approach was proposed by Müller et al. (2009) which is applicable for extended rainfall events. The method which involves combination of information on the permeability of the underlying lithology, slope and land use, but excludes information about soil gives the same number of DRP classes as those proposed by Scherrer and Naef (2003). Application of Geostatistical analysis (GIS-DRP) in delineating of DRPs at a regional scale require three basic datasets in terms of permeability: simplified geological map, digital elevation model and land use/cover map. The method involves using a digital terrain analysis to delineate slopes into classes, followed by classification of the underlying geological substrata as either impermeable or permeable and then classification of land use. The three factors are subsequently combined to derive the prevailing DRPs.

In this study, DRP was evaluated using GIS-based automatic geo-statistical (GIS-
DRP) approach developed by Müller et al (2009). This approach was preferred because it requires less input data as well as shorter computation time with higher accuracy when compared to other GIS based approaches (Müller et al. 2009). The approach offers a method to delineate DRPs where necessary information such as soil maps and soil profiles are lacking.

\section{Study area}

The study area is Anambra state which lies between latitudes $5^{\circ} 40^{\prime} \mathrm{N}$ and $6^{\circ} 35^{\prime} \mathrm{N}$ and longitude $7^{\circ} 10^{\prime} \mathrm{E}$ and $7^{\circ} 20^{\prime} \mathrm{E}$. It is characterized by tropical climate with rainy season between the March and October and dry season between November and February. The dry season is accompanied by cold dry Harmattan north-easterly trade wind from the Sahara desert. The rainy season is characterized by heavy and abundant rainfall with annual rainfall between $1400 \mathrm{~mm}$ in the northern region to about $2500 \mathrm{~mm}$ in the southern region. The average annual temperature is about $33^{\circ} \mathrm{C}$ (Onwuka et al. 2012). The vegetation is tropical rain forest intermingled by large overgrowth of shrubs, stunted trees and tall elephant grasses (Offodile 2014).

The study area show varying terrain. Three topographic relief units exist in the study area (Ofomata 1975). These are: the lowlands and plain together with river valleys; the cuestas; and the highlands. Elevation ranges from 5 $388 \mathrm{~m}$ above sea level. Moderately elevated highland occur in the south while lowland plains lie to the west, east, and north. These plains are nearly flat, however there are random extensive undulations which protrude above the flood plains. In regards to geomorphology, the area can be considered to be in matured geomorphic stage. This is evident by presence flood plains, hillslopes and valley sides on the landscape and a great disparity between the highest and the lowest 
points. The geology of the area has significant influence on topography and development of runoff and erosion. Highlands underlain by considerably stable lithology which resist development of gullies support the development of powerful runoff which rapidly moves downward to destroy low-lying areas (Ofomata 1981; Igwe 2012).

\section{Geology and hydrogeology of the study area}

The study area which is part of the Anambra Basin is underlain by sedimentary rocks of Maastrichtian to Tertiary age. Anambra basin is more or less triangular shaped depression covering an area of about $30,000 \mathrm{~km}^{2}$ extending southward from an area just below the confluence of River Niger and River Benue (Offodile 2014). The folding and uplift of Abakaliki region during the Aptian-Santonian has been linked with the evolution of the basin which resulted in the partitioning of the depocentre into Afikpo region and Anambra platform (Oboh-Ikuenobe et al. 2005). Before the folding and uplift event, the lithologies in Abakaliki area are the Asu River Group, Eze Aku Group and Agbani Sandstone/Awgu Shale. The emergence of the basin lead to the deposition of Nkporo Group, Mamu and Ajali Formations, Nsukka and Imo Formation, Ameki Group, and Ogwashi-Asaba Formation during the Campano-Maastrichtian, the Maastrichtian, the Palaeocene, the Eocene and the Oligocene respectively (Nwajide 1990).

Nkporo Shale, Oweli Sandstone and Enugu Shale constitute the Nkporo Group. Overlying the Nkporo Group is Mamu Formation which comprises of shale, coal and sandy shale. Overlying Mamu Formation is a thick, friable and poorly sorted white sandstone of Ajali Formation (Gideon et al. 2014; Reyment 1965). Above Ajali Sandstone, Nsukka Formation is observed. It consists of coarse to medium grained sandstones at the bottom but transforms into well-sorted blue clays, finegrained sandstones and carbonaceous shale with limestone at the top. Imo Formation overlying Nsukka Formation is a sequence of blue-grey clays, shale and black shales with bands of calcareous sandstone, limestone and marl (Oboh-Ikuenobe et al. 2005). Nanka sand, Nsugbe and Ameki Formations constitute the Ameki Group. The Ameki Formation is an interlayered sequence of sandy shale, shale, clayey, sandstone and fine-grained fossil bearing sandstone with thin bands of limestone (Oboh-Ikuenobe et al. 2005; Reyment 1965). The Ogwashi-Asaba Formation consist of terrigenous sediments of interlayered sequence of coarse-grained sandstone, light coloured clays and lignite seams (Oboh-Ikuenobe et al. 2005).

Hydrogeologically, the Ajali Formation (sandstone) is the most important aquiferous unit in the Anambra basin. In some places sandstones beds of Ajali Formation are confined to produce artesian conditions. The Nkporo and Mamu Formations consist majorly of shales, clays and coal seams, hence can best be considered as aquicludes or aquitards (Offodile 2014).

The drainage pattern in the study area is dendritic to sub-dendritic with the rivers discharging into River Niger on the west of the study area. The basin is drained primarily by Anambra River and its tributaries. The Anambra drainage system (Figure 1) flows approximately northeast-southwest joining the main body of River Niger at an oblique angle.

Anambra State has been adjudged as one of the worst hit by flood disaster and vulnerable state to flooding (NEMA 2012; Nwabineli 2013; Ebuzoeme 2015; AFO 2017) in Nigeria. Several causative factors such as soil's nature, high intensity of rainfall downpour, poor agricultural practices, illplanned engineered works (e.g. inavailabity, poorly distributed, narrow, shallow, poor clearance, and blockage of drainage channels), presence of heavy commercial centres (Awka, Onitsha and Nnewi areas), high population density and lack of enforcement of 
environmental sanitation regulations in the state have been reported to be responsible for the high vulnerability of the state to flooding (Efobi and Anierobi 2013; Anierobi 2010). Absence of vegetative cover which supports high surface runoff thereby exposes the soil to flooding and erosional activities also facilitates flooding in the state as well (Nwabineli, 2013). However, several parts of the state have continued to be affected by flooding over the years which successive State governments have not been able to provide solution. Several authors (e.g. Efobi and Anierobi 2013; Nwabineli 2013; Ebuzoeme 2015) employed several techniques to evaluate the effects of flooding in parts of the state that have been affected by flooding. The most widely used techniques include using questionnaire survey to acquire data from the residents of the flood affected areas, secondary data from official records of the State Ministry of Environment and statistical analysis on the acquired data. Their studies revealed the effects on flooding on some parts of the state (Iweka-Onitsha,
Umueje, Umuoba Anam, Umuleri, Aguleri, Odekpe, Igbaku, Iyiagu Awka, Eke-Awka, Agulu, Amaenyi, Ezi-Awka, Amikwo, Ifite, Nkwelle among others) in the forms of the following environmental woes such as loss of lives, socio-economic, cultural and religious activities disruption (industries submerged and no longer in operations), congestion of roads, accidents, building damages, people's properties destroyed (estimated 10,000 homes fully or partially submerged), health problems, reduction of aesthetic beauty of the environment, poverty rate increased, and high number of Internal Displaced Persons (and splintering of family ties). The frequent occurrence of runoff in form of flood has also be linked with the profusion of gullies in the state (Grove 1951; FAO 1990; Nwafor 2006). Although flood is a major recurrent environmental problem in the study area, there is a general absence of comprehensive and reliable hydrological data such as discharge recharge and potentials (Uma and Kehinde 1992).

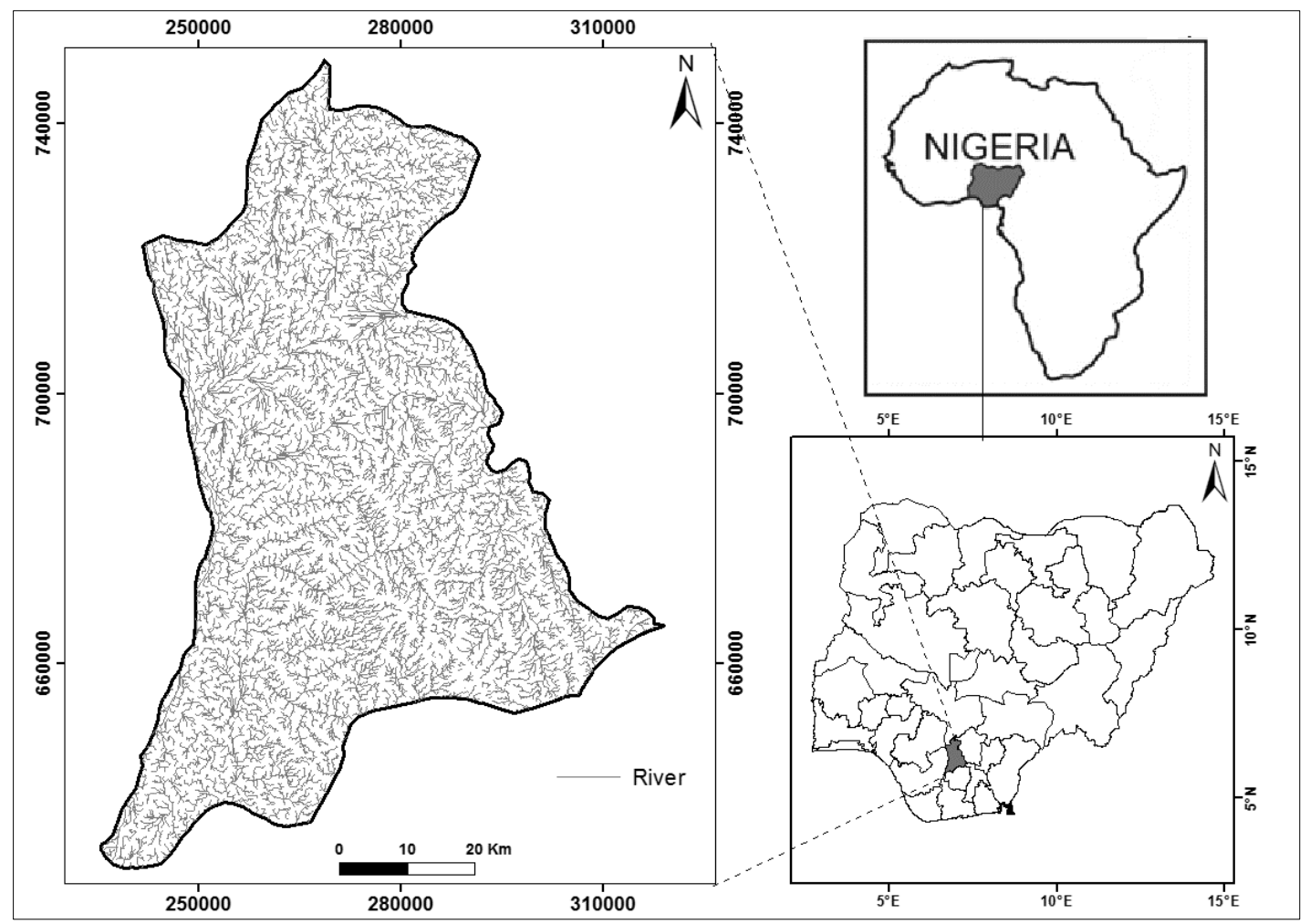

Fig.1. Drainage system of the study area. Inset Africa and Nigeria. 


\section{Data and methods}

GIS-DRP involves simplification of the technique developed by Scherrer and Naef (2003). The simplification is based on assumption that the DRPs are majorly influenced by the permeability of the substratum and slope.

In order to identify the DRPs in the study area adopting the method proposed by Müller et al. (2009), the following data were used: SRTM DEM with spatial resolution of 30.86 $\mathrm{m}$, Landsat 8 with $30 \mathrm{~m}$ spatial resolution and geological map. The Landsat 8 and SRTM DEM covering the study area were downloaded from http://earthexplorer. usgs.gov/. The first step in the generation of GIS-DRP is to classify slope into slope classes in accordance with the original decision scheme for field campaigns to determine dominant runoff processes (Scherrer and Naef 2003) from the DEM. Stream network was also generated from the DEM. In the second step, the geological substrata of the area are classified into permeable or impermeable. Permeability of the substratum is based on the lithological and geo-hydrological characteristic such as primary porosity and secondary porosity such as fractures. The land use/cover of the area was derived from Landsat data. All data were converted to vector and finally the permeability layer is linked to the developed land use map and the slope classes to determine the DRP for each of the polygons.

\section{Land use/cover}

Land use/cover is an important factor which influence runoff type occurring in an area. The type of use to which a land is subjected to can either support or reduce the development of runoff. Remotely sensed images provide reliable information on land use/cover. The land use/cover types in the study area was derived from Landsat 8 data.

The land use/cover types were obtained by classification of the Landsat data through supervised classification approach using maximum likelihood classifier in ENVI software. The land use/cover types in the study area are: arable farm, bare ground, built up, forest and waterbody as shown in Figure 2A. Arable land covers the largest area within the study area. The spatial coverage of the land use/cover types is presented in Table 1 .

Tab.1. Area covered by different land use/cover classes in the study area.

\begin{tabular}{lcc}
\hline Land use/cover & Area $\left[\mathrm{km}^{2}\right]$ & Percent area [\%] \\
\hline Arable land & 1596.3 & 35.2 \\
Bare ground & 151.7 & 3.4 \\
Built up & 1500.8 & 33.2 \\
Forest & 1219.6 & 26.9 \\
Waterbody & 58.4 & 1.3 \\
\hline
\end{tabular}

Slope

The gradient of slope is one of the factors that directly influence the runoff and infiltration of rainfall in that steeper slopes generate high runoff (Selvam et al. 2015). Flat areas with gentle slope are capable of holding rainfall, thereby enabling infiltration of water and reduction of formation of overland flow, whereas in areas where the slope amount is high, there will be high runoff due to rapid development of overland flow. The slope of the area was calculated in percentage using the surface analysis tool of spatial analyst in ArcGIS. The computed slope was reclassified based on its influence on formation of DRP as specified by Müller et al. (2009) (Figure 2B). The spatial coverage of the slope classes are presented in Table 2.

Tab.2. Slope classes in the study area

\begin{tabular}{ccc}
\hline Slope class [\%] & Area $\left[\mathrm{km}^{2}\right]$ & Percent area [\%] \\
\hline $0-3$ & 729.2 & 16.8 \\
$3-5$ & 1457.9 & 33.6 \\
$5-20$ & 2090.3 & 48.2 \\
$20-40$ & 62.0 & 1.4 \\
$>40$ & 0.3 & 0.007 \\
\hline
\end{tabular}




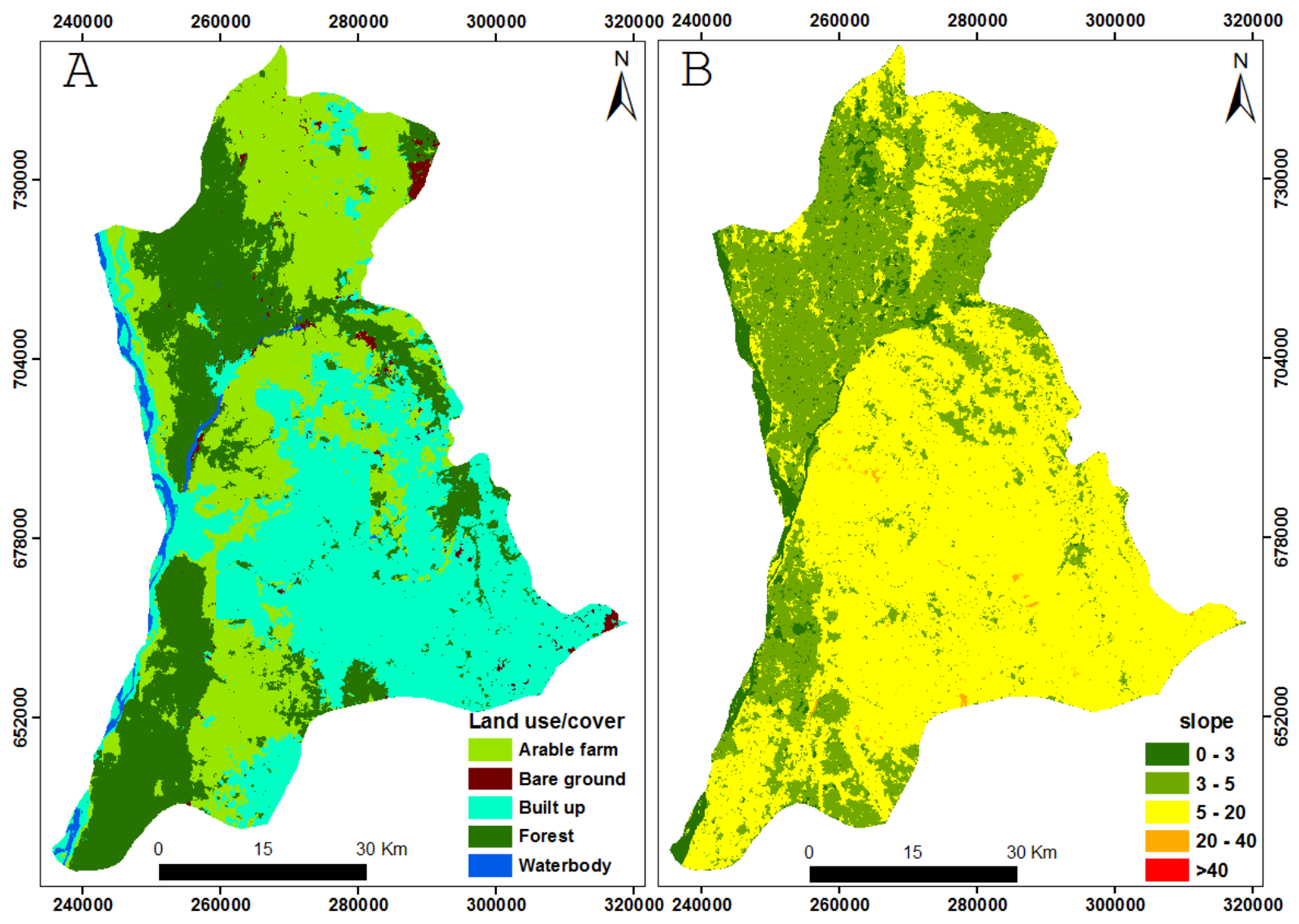

Fig.2. (A) Land use/cover, (B) Slope.

\section{Lithology}

In addition to slope and land use/cover, permeability of the substratum is another factor which greatly influence DRP in an area. The permeability of substratum determines the rate at which water infiltrates into the subsurface. Where the substratum is highly permeable, surface water infiltration is high resulting in DP, whereas in places where substratum is impermeable SOF or SSF tend to develop depending on the slope. The geologic map of the study area produced by The Nigerian Geological Survey in 2006 was georeferenced and digitized. The lithologies in the study area are: alluvium; clay-shale and sandstones; coal, shale and loose sands; mudstones, sandstones and lignite; siltstone, sands and sandstones (Figure 3). The lithologies were classified as either permeable or impermeable based on their characteristics.
The classification of the lithologies into permeable/impermeable is based on the Formation it belongs and dominant unit present. Siltstone, sands and sandstones belongs the Bende Ameki Formation including Nanka Sands. Clay-shale and sandstone belong to Imo shale Formation with Ebenebe sandstone. Coal, shale and loose sands belong to the Lower Coal Measure. Mudstones, sandstones and lignite belong to the Lignite Series (NGSA 2006).

The hydraulic conductivity Nanka Sands range from 179.71 to $730.94 \mathrm{~m} /$ day. These values are indicative of high permeability (Okoro et al. 2010). The Mamu Formation has a varied hydraulic conductivity due to heterogeneities. Values of hydraulic conductivity of the formation ranges from 0.6912 to $345.6 \mathrm{~m} /$ day (Egboka and Uma 1985). Previous borehole tests within the alluvium unit indicates a transmissivity value 
of $210.3 \mathrm{~m}^{2} /$ day suggestive of high permeability. The mudstone, sandstone and lignite series of Ogwashi-Asaba Formation has transmissivity value ranging between 37.51 $95.5 \mathrm{~m}^{2} /$ day, while the transmissivity of Imo Shale is estimated to be around $3.1 \mathrm{~m}^{2} /$ day which is suggestive of very low permeable material (Nfor et al. 2007)
Imo shale Formation with Ebenebe sandstone, Lower Coal Measure and Lignite Series were classified as impermeable while Bende Ameki Formation including Nanka Sands and Alluvium were classified as permeable. The spatial coverage of each lithology is provided in Table 3.

Tab.3. Area covered by different rock types

\begin{tabular}{lll}
\hline Lithology & $\begin{array}{l}\text { Area } \\
\left(\mathrm{km}^{2}\right)\end{array}$ & $\begin{array}{l}\text { Percent area } \\
(\%)\end{array}$ \\
\hline Alluvium & 974.9 & 21.3 \\
Clay-shale and sandstones & 1156.3 & 25.2 \\
Coal, shale and loose sands & 42.4 & 0.9 \\
Mudstones, sandstones and lignite & 993.3 & 21.6 \\
Siltstone, sands and sandstones & 1421.6 & 31.0 \\
\hline
\end{tabular}

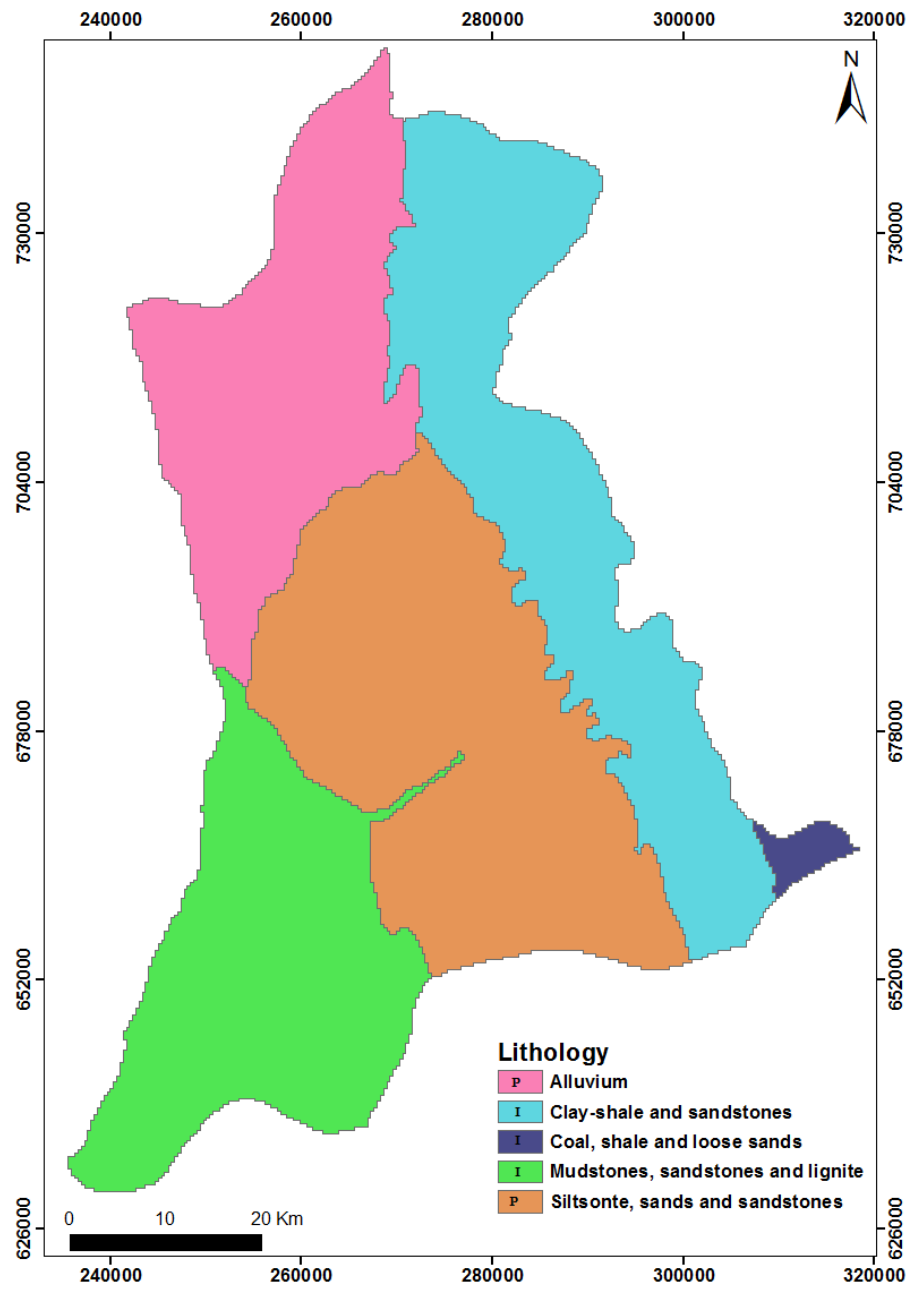

Fig.3. Geological map of the study area. (Adapted after Nigerian Geologic Survey Agency 2006). Note I and P in the legend indicate impermeable and permeable. 


\section{Data integration}

The integration of the factors to identify DRP was based on the classification in Table 4. The three factors: slope, geology and land use/cover were converted into vector for data integration. Union vector overlay analysis was used to integrate the three factors to determine the DRP in the study area. Union overlay analysis calculates the geometric union of the three feature classes by cracking and clustering the features class and then identifying geometric overlaps between features from all classes. The resulting feature class contains polygons with all the attributes from all the input feature classes. Identification of polygon with a particular DRP characteristic was done by systematic querying.

\section{Results and discussions}

The DRPs for the study area generated through the integration of slope, geology and land use/cover of the study area is presented in Figure 4 while the statistics for the DRPs are presented in Table 5. The Hortonian overland flow covers the largest area within the study area with an area coverage of $1508.3 \mathrm{Km}^{2}$ $(33.5 \%)$. This is due to the prominence of built-up area underlain by compact permeable formation. The prominence of built-up in this area can be linked to availability of groundwater which may be accessible through various means.

Deep percolation covers the second largest area of $1455.3 \mathrm{~km}^{2}(32.3 \%)$ occurring largely in area underlain by alluvium. The areas where DP prevails represents potential zones of groundwater recharge and can be expected have abundant groundwater that can serve for several purposes. SSF covers an area of 920.6 $\mathrm{km}^{2}(20.4 \%)$ of the study area, due to the shallow depth of the soil and presumably lateral flow paths of water. This amount can also contribute to groundwater recharge and sometimes burst out as springs to the nearby river channel. SOF covers the lowest area coverage of $618.14 \mathrm{~km}^{2}(13.7 \%)$ of the study area due to appreciable degree of soil saturation and filled depression storage.

The large variation in elevations in the area support the development a terrain with high amount of slope angle and length which in combination with sparse vegetal cover favours formation of runoff. This can be linked to recurrent flood problem experienced in the study area (Nwabineli, 2013). The excessive runoff generated during rainstorms has led to severe erosion problem in the area as it rapidly accelerates the development of gullies from incipient interrill and rill channels (Igwe 2012). Efforts to curtail gully erosion by controlling the amount of HOF getting to the channels through roofwater harvesting has been adopted in the past with considerably success when properly managed (Hudec et al. 2005). Harvesting of flood flows from valleys, gullies, and ephemeral streams and storing in ponds, small reservoirs and weirs will further reduce erosion rates in the area.

Tab.4. The assumed dominant runoff processes (DRP) based on slope and permeability of the substratum for grassland, arable land and forest (after Müller et al. 2009)

\begin{tabular}{|c|c|c|c|}
\hline $\begin{array}{l}\text { slope } \\
\%\end{array}$ & $\begin{array}{l}\text { Impermeable substratum } \\
\text { Grass -and arable land }\end{array}$ & $\begin{array}{l}\text { Impermeable substratum } \\
\text { Forest }\end{array}$ & $\begin{array}{l}\text { Permeable substratum } \\
\text { Grass-, arable land and forest }\end{array}$ \\
\hline $0-3$ & $\mathrm{D}_{\mathrm{SOF} 3}$ & $\mathrm{D}_{\mathrm{SOF} 3}$ & $\mathrm{D}_{\mathrm{DP}}$ \\
\hline $3-5$ & $\mathrm{D}_{\mathrm{SOF} 2}$ & $\mathrm{D}_{\mathrm{SSF} 3}$ & $\mathrm{D}_{\mathrm{DP}}$ \\
\hline $5-20$ & $\mathrm{D}_{\mathrm{SSF} 2}$ & $\mathrm{D}_{\mathrm{SSF} 2}$ & $\mathrm{D}_{\mathrm{DP}}$ \\
\hline $20-40$ & $\mathrm{D}_{\mathrm{SSF} 1}$ & $\mathrm{D}_{\mathrm{SSF} 2}$ & $\mathrm{D}_{\mathrm{DP}}$ \\
\hline$>40$ & $D_{\text {SSF1 }}$ & $D_{\text {SSF1 }}$ & $D_{\mathrm{DP}}$ \\
\hline
\end{tabular}


Tab.5. Spatial distribution of dominant runoff process

\begin{tabular}{ccc}
\hline DRP & Area $\left[\mathrm{km}^{2}\right]$ & Percent area [\%] \\
\hline D $_{\text {DP }}$ & 1455.3 & 32.3 \\
D HOF & 1508.3 & 33.5 \\
DSOF2 & 348.0 & 7.7 \\
DSOF3 $_{\text {DSS1 }}$ & 270.4 & 6.0 \\
D $_{\text {SSF2 }}$ & 5.8 & 0.2 \\
D $_{\text {SSF3 }}$ & 661.9 & 14.7 \\
\hline
\end{tabular}

Comparison of automated derived DRPs to a field derived DRP map was impossible as there is no existing DRP map for the study area. Since the simplification of data is applied to obtain a simple rainfall-runoff model, direct calibration of result against measured runoff would some present ambiguities simply because the delineated DRP represents the process that will dominate after prolonged rainfall or rainfall of high intensity, while deviations from these delineated DRP can be occur during low intensity rainfall of short duration. Validation of the derived DRP can however be achieved by comparison of the delineated DRP to a DRP map obtained by manual approach which involves detailed field investigation. Previous studies have shown considerably similarity between DRPs obtained using this approach with reference maps (Müller et al. 2009; Antonetti et al. 2016). However discrepancies exist where geological map is inaccurate. Geological maps are usually not fine enough to represent minor variations in geological formations. Generalization results in the omission of units too small to be depicted at which the scale the geological map produced. Such omissions can result in variation between the automated derived DRP and prevailing condition on ground. The resolution of the input DEM and land use data can also result in uncertainties. Where resolution of the input data are too coarse, discrepancies are bound to exist between predicted DRP and exact condition. These problem can however be minimized by the use high resolution DEM and derivation of land use from high resolution satellite image.

Although the result obtained from this study is a simplistic rainfall-runoff model depicting conditions expected during and/or after prolonged rainfall event, the result is however useful as it can serve as a starting point for detailed hydrological modelling particularly in an ungagged basin such as the study area whilst providing an insight into the prevailing runoff process at a regional scale. Furthermore, validation of the derived DRPs using infiltration experiments in combination with tracer techniques can enable upscaling of the derived DRPs into dominant hydrological process.

\section{Conclusion}

The objective of this study was to delineate DRPs at a regional scale for Anambra State. To achieve this, three factors namely slope, land use and geology which majorly influence runoff process were combined in a GIS environment to determine the DRPs in the study area. A simplified approach involving evaluation permeability of substratum together with slope and land use/cover classification was adopted. This approach was preferred because it gives higher accuracy and requires less input data as well as shorter computation time when compared to other GIS based approaches. Although the approach is a straight forward and fast method for delineation of DRPs, it however gives acceptable accuracy particularly at mesoscale 


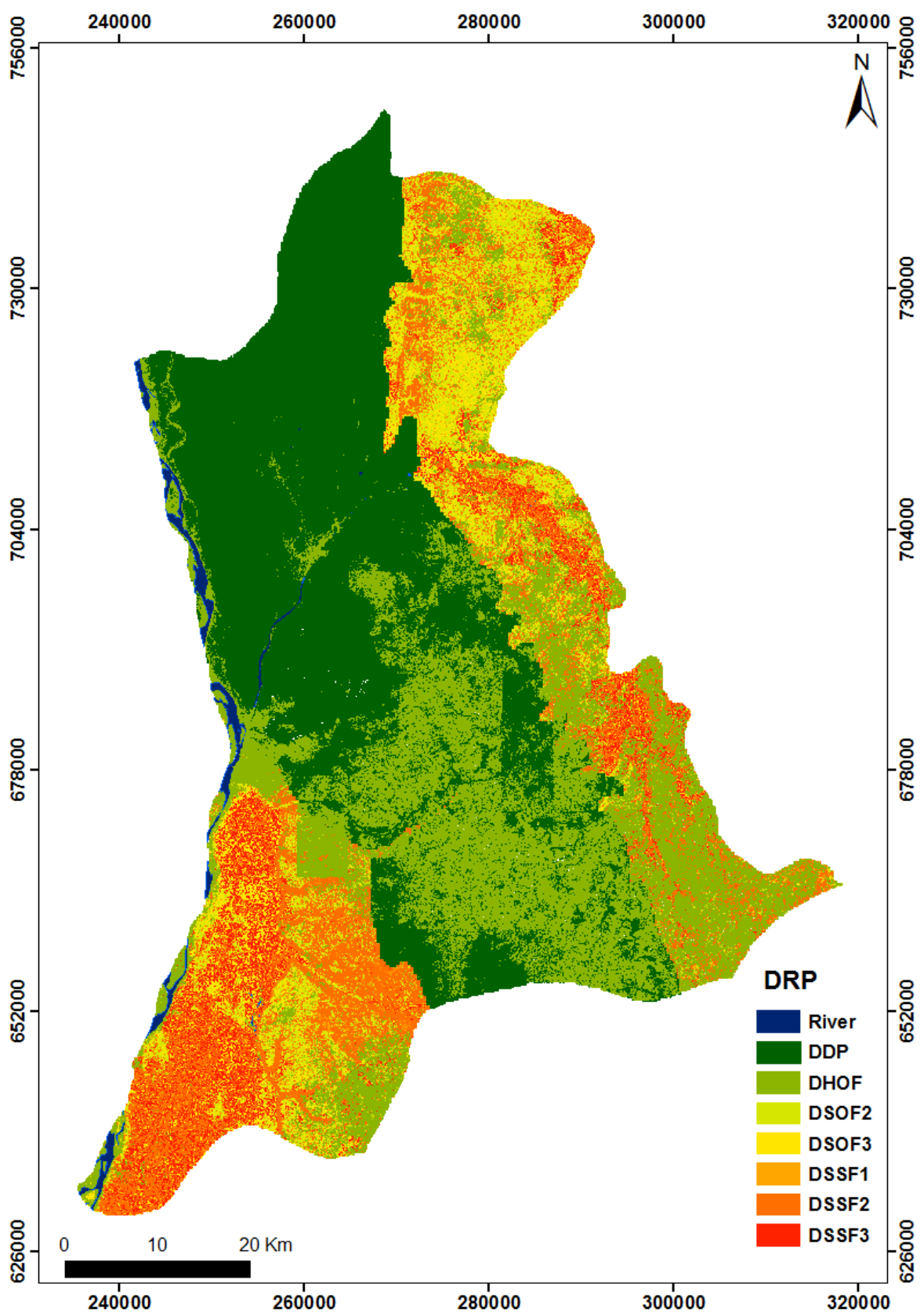

Fig.4. Dominant Runoff Process Map of the study area

basin level when compared to other approaches.

The delineated DRPs (HOF, DP, SSF and SOF) represent the spatial distributions of the prevailing runoff processes in the study area. HOF covers the largest area within the study area, with an area coverage of $1508.3 \mathrm{~km}^{2}$ $(33.5 \%)$. This is followed by deep percolation with area coverage of $1455.3 \mathrm{~km}^{2}(32.3 \%)$. SF is third most abundant DRP with an area coverage of $920.6 \mathrm{~km}^{2}$ (20.4\%), while SOF have the least coverage, covering an area of $618.4 \mathrm{~km}^{2}(13.7 \%)$ It is presumed that considerable amount of precipitated water would be infiltrated into the subsurface thereby contributing to groundwater recharge in the study area.

The combined area covered surface and near surface processes (HOF, SSF and SOF) will support flooding, erosion, and worst 
environmental conditions in the nearest future if the present precipitation pattern persists coupled with its associated urban growth. Considering the combined area covered by $\mathrm{HOF}$ and SOF, and the changing rainfall pattern associated with climate change, it is imperative that proper planning be considered for groundwater recharge in order to ensure its sustainable use in the future. The area characterized by DP process need to be safeguarded for sustainable use of groundwater. The result of this study can be useful for relevant environmental management agencies in evaluation of potential zones of groundwater recharge and monitoring of erosion and deposition rates with the view of future planning in the study area.

The results of this work have important implications in terms of flood management, groundwater resource management and regional soil conservation. The main contributions of this work can be summarized as follow: i) contribution to flood hazard mitigation: this study provides an overview of the dominant runoff processes in the study area which can be relevant for mitigation of flash floods commonly associated with HOF in built up area; ii) contribution to the field of water resource management: understanding of the dominant runoff processes occurring in an area is essential to identification of zones of groundwater recharge which is vital in conservation of groundwater against pollution: iii) contribution to the field of soil conservation: one of the major environmental problems in the study area is soil loss due to water erosion which has resulted in the developments of gullies and badlands. Identification of the dominant runoff processes prevailing in different parts of the study area can help in the development of and implementation measures against soil erosion.

\section{Acknowledgment}

The authors appreciate meticulous reviews and meaningful suggestions by Rafal Ulanczyk and
Joanna Czekaj which significantly improved the manuscript

\section{References}

Aladejana O.O., Anifowose A.Y.B., Fagbohun B.J. (2016) Testing the ability of an empirical hydrological model to verify a knowledge based groundwater potential zone mapping methodology. Modeling Earth Systems and Environment, 2: 174. doi 10.1007/s40808-016-0234-3

Anambra State Ministry of Environment (2012) Official gazette, Awka

Anierobi C.M. (2010) An Assessment of Anambra State Environmental Protection Agency (ANSEPA) in urban management of Anambra State, Nigeria

Antonetti M., Buss R., Scherrer S., Margreth M., Zappa M. (2016) Mapping dominant runoff processes: an evaluation of different approaches using similarity measures and synthetic runoff simulations. Hydrology and Earth System Science 20, 2929-2945. doi:10.5194/hess-20-2929-2016

Annual Flood Outlook. AFO. (2017) Federal Government to States, Council areas: brace for floods. Punch Newspaper, Friday September 8, 2017, 2-3.

Bonell M. (1998) Selected challenges in runoff generation research in forests from the hillslope to headwater drainage basin scale. Journal of the American Water Resources Association 34 (4), 765-785.

Ebuzoeme O.D. (2015) Evaluating the Effects of Flooding in Six Communities in Awka Anambra State of Nigeria. Journal of Environment and Earth Science, 5, 4, 2638.

Efobi K., Anierobi C. (2013) Urban Flooding and Vulnerability of Nigerian Cities: A case study of Awka and Onitsha in Anambra State, Nigeria. Journal of Law, Policy and Globalization, 19, 58-64.

Faeh A. O. (1997) Understanding the processes of discharge formation under extreme 
precipitation; A study based on the numerical simulation of hillslope experiments, Mitteilung der Versuchsanstalt für Wasserbau, Hydrologie und Glaziologie, ETH Zürich, 150.

Egboka B.C., Uma K. (1985) Acid mine drainage problems in Enugu Coal Mines of Anambra State, Nigeria. In: Mine Water (Proc. International Mine Water Assoc, Granada, Spain), 1(1), 1-13.

Fagbohun B.J., Anifowose A.Y.B., Odeyemi C., Aladejana O.O., Aladeboyeje A.I. (2016) GIS-based estimation of soil erosion rates and identification of critical areas in Anambra sub-basin, Nigeria. Modeling Earth Systems and Environment, 2: 159 . doi 10.1007/s40808-016-0218-3

FAO (1990) Nigeria: land resources management study. Annex 6: proposals for improved soil and water management in representative (pilot) areas, Appendix 1: The very humid zone, Food and Agriculture Organization, Rome

Gharari S., Hrachowitz M., Fenicia, F., Savenije H.H.G. (2011) Hydrological landscape classification: investigating the performance of HAND based landscape classifications in a central European mesoscale catchment, Hydrology and Earth System Science 15, 3275-3291, doi:10.5194/hess-15-3275-2011.

Gideon Y.B., Fatoye F.B., Omada J.I. (2014) Sedimentological characteristics and geochemistry of Ajali Sandstone exposed at Ofe-Jiji and environs northern Anambra Basin, Nigera. Research Journal of Environmental and Earth Sciences, 6(1), 10-17.

Gliński J., Horabik J., Lipiec J. (Eds). (2011) Encyclopaedia of Agrophysics. Institute of Agrophysics, Polish Academy of Sciences, Lublin, Poland.

Grove A.T. (1951) Soil erosion and population problems in south-east Nigeria, Geographic Journal, CXVII, 3, 291-306.
Hudec P.P., Simpson F., Akpokodje E.G., Umenweke M. (2005) Anthropogenic contribution to gully initiation and propagation, SE Nigeria. In J. Ehlen, W. Haneberg, \& L. R.A (Eds.), Humans as Geologic Agents, Geological Society of America Reviews in Engineering Geology, XVI, Geological Society of America, Boulder, Colorado, 149-158.

Hümann M., Müller C. (2013) Improving the GIS-DRP approach by means of delineating runoff characteristics with new discharge relevant parameters, ISPRS International Journal of Geo- Information, 2, 27-49, doi:103390/ijgi2010027.

Igwe C.A. (2012) Gully Erosion in Southeastern Nigeria: Role of Soil Properties and Environmental Factors. In Research on Soil Erosion. Danilo Godone (Ed), InTech, doi; 10.5772/51020

Müller C., Hellebrand, H., Seeger, M., Schobel S. (2009) Identification and regionalization of dominant runoff processes - a GISbased and a statistical approach. Hydrology and Earth System Science 13, 779-792.

Naef F. Scherrer S., Weiler M. (2002) A process based assessment of the potential to reduce flood runoff by land use change. Journal of Hydrology 267, 74-79.

National Emergency Management Agency, NEMA. (2012) Annual Report on Flood, Official gazette, Abuja

Nfor B.N., Olobaniyi S.B., Ogala J.E (2007) Extent and Distribution of Groundwater Resources in Parts of Anambra State, Southeastern, Nigeria J. Appl. Sci. Environ. Manage, 11(2) 215 - 221

Nigerian Geologic Survey Agency. (2006) Geological Map of Nigeria

Nwabineli E.O. (2013) Gully and Flooding in Anambra State: the way forward. Journal of Environment and Earth Science. 3, 12, 152-154.

Nwafor J.C. (2006) Environmental Problems in Nigeria and Povert Environment Links. Environmental Impact Assessment for 
Sustainable Development, The Nigerian Perspective. Erosion- pp521-522, ISBN 978-38567. Environment and Development Policy Center (EDPCA).

Nwajide C.S. (1990) Cretaceous sedimentation and palaeogeography of Central Benue Trough. In C. O. Ofoegbu (Ed.), The Benue Trough Structure and Evolution, Braunchweig/Wiesbaden: Friedr. Viewed and Sohn, 19-38.

Oboh-Ikuenobe F.E., Obi C.G., Jaramillo C.A. (2005) Lithofacies, palynofacies, and sequence stratigraphy of Palaeogene strata in Southeastern Nigeria. Journal of African Earth Sciences, 41, 79-101.

Offodile M.E. (2014) Hydrogeology: Ground water study and development in Nigeria. Third Edition. Mecon Geology \& Engineering Services Ltd.

Ofomata G.E.K. (1975) Soil erosion. Nigeria in maps, Eastern States, Ethiope Publishing House, Benin City Nigeria.

Ofomata G.E.K. (1981) Actual and potential erosion in Nigeria and measures for control. Soil Science Society of Nigeria Special Monograph, 1, 151-165.

Okoro E.I., Egboka B.C.E., Anike O.L., Enekwechi E.K. (2010) Evaluation of Groundwater Potentials in parts of the escarpment areas of southeastern, Nigeria. International Journal Of Geomatics And Geosciences, 1(3): 544-551.

Onwuka S.U., Okoye C.O., Nwogbo N. (2012) The place of soil characteristics on soil erosion in Nanka and Ekwulobia communities in Anambra State. Journal of Environmental Management and Safety, 3(3), 31-50.
Reyment R.A. (1965) Aspect of the Geology of Nigeria. University of Ibadan Press, Nigeria.

Sharma T., Satya K.P.V., Singh T.P. Trivedi A.V., Navalgund R.R. (2001) Hydrologic Response of a watershed to land use changes. Int J Remote Sens, 22(11), 20952108

Scherrer S., Naef F. (2001) A decision scheme to identify dominant flow processes at the plotscale for the evaluation of contributing areas at the catchment-scale, in: Runoff generation and implications for river basin modelling, edited by: Leibungut, C., Uhlenbrook, S., and McDonnell, J., (Freiburger Schriften zur Hydrologie, 13), Freiburg, Germany, 11-16.

Scherrer S., Naef F. (2003) A decision scheme to indicate dominant hydrological flow processes on temperate grassland, Hydrol. Process. 17, 391-401, doi:10.1002/hyp.1131.

Schmocker-Fackel P., Naef F., Scherrer S. (2007) Identifying runoff processes on the plot and catchment scale, Hydrology and Earth System Science 11, 891-906, doi:10.5194/hess-11-891-2007.

Selvam S., Dar F. A. ,Magesh N.S., Singaraja C., Venkatramanan S. (2015) Application of remote sensing and GIS for delineating groundwater recharge potential zones of Kovilpatti Municipality, Tamil Nadu using IF technique. Earth Science Informatics doi 10.1007/s12145-015-0242-2

Uma K.O., Kehinde M.O (1999) Quantitative assessment of the groundwater potential of small basins in parts of southeastern Nigeria. Hydrological Sciences, 37: 4(8) 